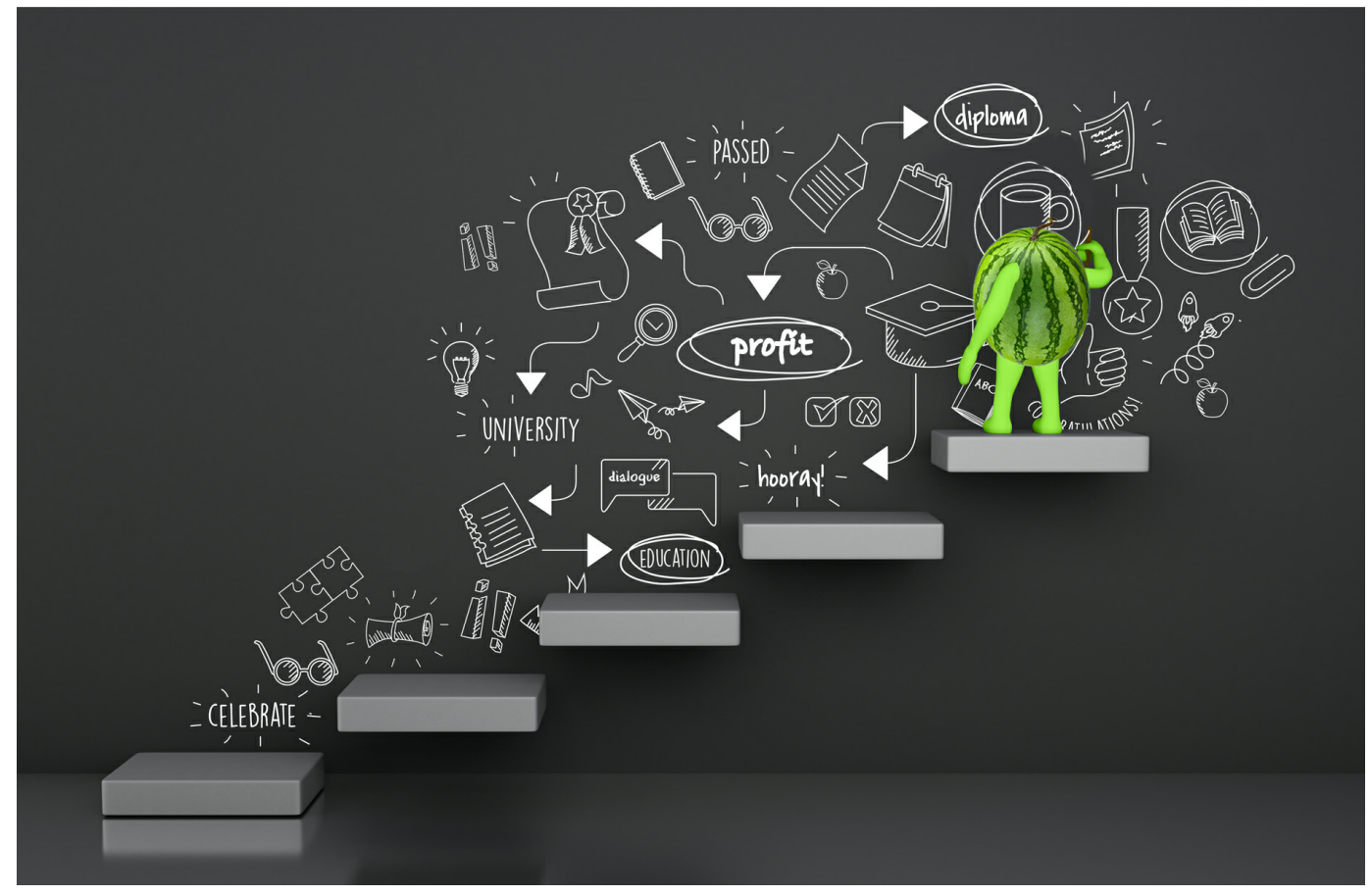

NEW GENERATIONS OF STUDENTS FROM THE PERSPECTIVE OF VALUE CO-CREATION AT UNIVERSITY 


\section{NEW GENERATIONS OF STUDENTS FROM THE PERSPECTIVE OF VALUE CO-CREATION AT UNIVERSITY}

\section{Professor Mirosława Pluta-Olearnik}

Wroclaw University of Economics, Faculty of Management, Department of Marketing miroslawa.pluta-olearnik@ue.wroc.pl •ORCID 0000-0002-5719-4710

DOI: 10.2478/minib-2019-0049

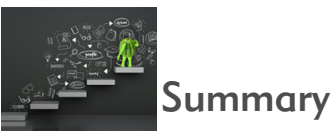

At the turn of the 20th and 21 st centuries, new paradigms emerged regarding the value creation in management and marketing in organizations. They causes also redefining the role of universities as a service organization and participants in the process of higher education (including especially students, lecturers, management). In this context, the current and important research problem appears to be the impact of new generations of students, exhibiting different attitudes and purchasing behaviors from on the image of a modern university. A particular challenge for the higher education organization is therefore the problem not only of creating and delivering the expected value as part of the education service, but the issue of shaping positive educational experiences with the active participation of actors in the entire education cycle.

The aim of the article is to identify the attitudes and behavior of the young generation of students at Polish universities and to diagnose their potential in the process of co-creating the value of an educational service. By adopting the paradigm of co-creating a service based on variables such as co-production, relationships and experience, we can determine the possibilities of formulating the strategy and image of Polish universities. In particular we focus on chances of implementing the co-creating concept of an educational service at a higher level from a student's perspective. The article reviews secondary research based on foreign and polish literature and — on this basis - indicates different behavioral students styles and their readiness to participate in co-creating the educational service at the university. The diagnosis and final conclusions refer to the results of studies carried out in 2017 at selected polish economic universities, in the field of management, and published by Polish researchers in reputable scientific journals and books.

Keywords: new generations, $\mathrm{Y}$ and $\mathrm{Z}$ generation, value in services, value co-creation in educational services, university, educational process 



\section{Introduction}

Modern universities undergo important transformations under the influence of changing conditions of the global environment, especially demographic, technological, economic and social ones. At the turn of the 20th and 21st centuries, new paradigms concerning management and marketing in organizations appeared, which also redefine the role of universities as a service organization and the role of participants in the process of higher education (especially students, lecturers, management). In this context, the influence of new generations of students, manifesting different attitudes and purchasing behaviours on — broadly speaking - the image of a modern university, appears to be a current and important research problem. A particular challenge for the organisation of higher education in Poland is currently not only the problem of creating and delivering the expected value within the educational service, but also the issue of shaping positive educational experiences with the active involvement of participants taking part in the whole cycle of education. The main participants certainly include university students who currently represent the new generations known as the $\mathrm{Y}$ and $\mathrm{Z}$ generations, who are attributed with specific features. Therefore, the aim of the article is to present, on the basis of analysis of secondary sources, styles of behaviour of the young generation of students at Polish universities and their own diagnosis of their potential in value co-creating of educational services in the educational process. By adopting - on the basis of literature research - a paradigm concerning co-creation of a service based on variables such as co-production, relations and experience, we can determine the possibilities of formulating the strategy and image of Polish universities and the chances of implementing the concept of co-creation of educational services from the student's perspective. The article reviews current research based on foreign and Polish literature and - on this basis describes segments of Polish students representing different styles of behavior and assesses their readiness to participate in the co-creation of educational services at the university. The analysis and diagnosis of the phenomenon refer to the results of empirical studies published by other researchers, carried out in selected Polish economic universities. 
However, their originality and value in the cognitive and methodological dimension means that they may have an impact on the fields of research and practice of higher education management in modern universities and are worth continuing. Certainly, the specificity of expectations and behaviours of new generations is a difficult challenge for universities which on one hand want to refer to the past and tradition, and on the other hand face the challenges of contemporary changes in the social, economic and technological environment.

\section{Generational changes and their implications for research}

The article refers to two important phenomena which determine the functioning of higher education in the 21st century and include, first of all, demographic changes in the university environment and, secondly, a new approach to marketing. Successively, we will indicate the importance of these determinants for contemporary universities, referring to the findings of researchers.

The essence of demographic changes can be graphically related to the generational distribution that was noticed in Western societies (Van der Bergh, Behrer (a), 2012; Tapscott, 2010). Researchers present the current generational distribution most often distinguishing five generations: war generation, baby boom generation (Baby Boomers, Silver tsunami), $\mathrm{X}$ generation, $\mathrm{Y}$ generation, $\mathrm{Z}$ generation (C). A brief description of the successive generations is presented in Table 1.

Next, we will focus on the specificity of behaviours of people from generation $\mathrm{Y}$ and generation $\mathrm{Z}$, in terms of their belonging to diverse groups (segments) of students of modern universities. Students' attitudes and values are an important condition for the development of the strategy and image of the university. The problem is important not only in the light of necessary changes in the offer and organisation of education at universities (study programmes, forms of classes, individualisation of studies), but it already has an impact on the management of the multitude of employees involved in education, i.e. 
research and didactic employees (who combine scientific and didactic activity) and didactic employees (involved only in the educational process). In the context of the issues raised, both groups of university staff will face strategic challenges for the future of the university.

Table 1. Characteristics of successive generations

\begin{tabular}{|c|c|c|}
\hline Generation name & Years of birth & Behavioural characteristics of generational representatives \\
\hline War generation & born before $\mathbf{1 9 4 5}$ & $\begin{array}{l}\text { - currently retired, } \\
\text { - strongly attached to tradition, } \\
\text { - with a high need for stability, } \\
\text { - conservative, } \\
\text { - with a sense of social and political responsibility. }\end{array}$ \\
\hline $\begin{array}{l}\text { The post-war baby } \\
\text { boom generation } \\
\text { (Baby Boomers or } \\
\text { Silver tsunami) }\end{array}$ & $\begin{array}{l}\text { born after WW II, } \\
\text { in years 1946-1964 }\end{array}$ & $\begin{array}{l}\text { - focused on material benefits, } \\
\text { - willing to make sacrifices at work, } \\
\text { - important values: work ethics and respect } \\
\text { - emotional openness, } \\
\text { - the first generation treating retirement massively as an } \\
\text { opportunity for self-fulfilment, not for withdrawal from } \\
\text { the world and passive family support. }\end{array}$ \\
\hline $\begin{array}{l}\text { Generation } X \text { of } \\
\text { demographic } \\
\text { decline }\end{array}$ & $\begin{array}{l}\text { born in } \mathbf{1 9 6 5 - 1 9 7 6} \\
\text { (another version: } \\
\text { 1965-1980) }\end{array}$ & $\begin{array}{l}\text { - confident, independent, } \\
\text { - who value the balance between work and private life, } \\
\text { - well educated, } \\
\text { - they'd love to work in their own company, } \\
\text { - not very responsible, carefree, } \\
\text { - they use many means of communication, but e-mail and } \\
\text { telephone are basic communication tools. }\end{array}$ \\
\hline $\begin{array}{l}\text { Generation Y } \\
\text { ("Millennials") }\end{array}$ & $\begin{array}{l}\text { Born in 1977-1997 } \\
\text { (another version: } \\
\text { 1980-2000) }\end{array}$ & $\begin{array}{l}\text { - use modern technologies (otherwise: generation "defined" } \\
\text { by Google, Facebook), } \\
\text { - see the value of social work, } \\
\text { - value trust and tolerance, } \\
\text { - like feeling active, } \\
\text { - do not tolerate emphasizing the hierarchy. }\end{array}$ \\
\hline $\begin{array}{l}\text { Generation } \mathbf{Z} \\
\text { (Digital Naatives } \\
\text { or generation C } \\
\text { meaning Connected } \\
\text { generation) }\end{array}$ & $\begin{array}{l}\text { born after } \mathbf{1 9 9 8} \\
\text { (another version: } \\
\text { after 2000) }\end{array}$ & $\begin{array}{l}\text { - The mobile generation that has been exposed to online media } \\
\text { since kindergarten, } \\
\text { - live with continuous access to the Internet and make strong use } \\
\text { of new technologies introduced to the market, } \\
\text { - prefer to read an e-book instead of a traditional book, } \\
\text { - Real life and interpersonal contacts are often replaced by contacts } \\
\text { in the virtual world. }\end{array}$ \\
\hline
\end{tabular}

Source: Own elaboration based on the data available: Van der Bergh, Behrer (a), 2012;

Tapscott, 2010; Gadomska-Lila, 2015; Gołąb-Andrzejak, 2016. 


\section{The specificity of generations $Y$ and $Z$ in the light of past research}

There were many myths around Generation $\mathrm{Y}$. They concerned both personal life (problems with entering adulthood, lack of independence, crisis of values), professional life (large claims against employers, low loyalty, high financial requirements) and consumer life. These stereotypes resulted from the lack of in-depth observation of the needs and motivations of the generation $\mathrm{Y}$ and from the fact that only a few years ago most of the representatives of this generation still shaped their identity. Recent years have brought many valuable research results which allow for a better understanding of the turn-of-the-century generation, and thus for establishing lasting relations with its representatives. Below, we will present the main observations of the researchers of this phenomenon.

Firstly, Millennials are an attractive target group, because communication with them is simpler, faster and cheaper than ever before. This is due to the fact that the common generation $\mathrm{Y}$ is growing up in the environment of modern technologies. Universal access to the Internet and the development of mobile devices caused that for Millennials there is no separate virtual and real space - these two worlds strongly intertwine, and social media coverage confirms the existence of an individual. On the other hand, disappearance from virtual space may contribute to the exclusion of young people, e.g. informational one (Kisiel, 2016).

Secondly, the rapid development of modern technology and growing up in an open environment (free movement of people, information, goods) have made generation $\mathrm{Y}$ the first global generation. Describing the Millennials, they are attributed with greater flexibility and openness to change than in the case of previous generations, readiness to learn and reluctance to long-term commitments, and are associated with the need to adapt to a rapidly changing environment. Having a good education, knowledge of foreign languages and new technologies makes the representatives of generation $\mathrm{Y}$ well prepared to move in areas related to the global economy and cultural diversity (Gadomska-Lila, 2015). 
Thirdly, generation $\mathrm{Y}$ differs from previous generations in terms of mentality, worldview, self-perception, work and sense of achievement.

Although the $\mathrm{Y}$ generation is focused on self-development, it promotes personalisation, and it is also a very committed generation. This can mean willingness to be part of many communities, but also to support environmental initiatives or active participation in social movements (Nielsen Company 2014). Research shows that, compared to previous generations, Millennials are much more open and tolerant (Viacom International Media Networks, 2017). Millennials have high ambitions and are strongly focused on development, and at work they look for opportunities to gain new experiences, realize their passions and interests and use new technologies (Rusak, 2014).

Fourthly, Millennials grew up in the times of developed consumerism and were surrounded by advertising messages from childhood. Contemporary research indicates that this has contributed to the development of a kind of "resistance" to marketing activities. Therefore, it is important to create a long-term communication strategy based on dialogue, trust and non-standard methods of communication (Van den Bergh, Behrer (b) , 2012). Communication to the Y generation should include the use of social media, experience and personalization marketing, messages and the product/service itself.

Fifthly, the $\mathrm{Y}$ generation, in addition to many advantages, is also attributed to certain shortcomings, including difficulties in adapting to the rules and procedures prevailing in companies. In addition, Millennials are accused of a low level of discipline at work and lack of acceptance by superiors. It is difficult to count on the loyalty of the representatives of this generation, because they are reluctant to identify themselves with the company and attach themselves to the workplace and make quick decisions about changing jobs, if they have the right opportunity to do so. Therefore, gaining loyalty and retaining a valuable representative of this generation is a real challenge for the employer (Albrychiewicz-Słocińska, Robak, 2017). 
Currently, the youngest generation of students at Polish universities also includes representatives of the next generation $\mathrm{Z}$ (also known as generation $\mathrm{C}$ - the Connected Generation or post-millennials or Digital Natives generation), i.e. those born after 1998, at a time of dynamic growth of the Internet and new communication technologies (mobile). The specificity of this generation is that their natural environment is modern technologies and the Internet. Compared to the previous generation, known as the $\mathrm{Y}$ generation which was only just learning the digital world, for the $\mathrm{Z}$ generation, modern technologies are something that has always existed.

According to researchers, the $\mathrm{Z}$ generation can do several things at the same time - they can talk to someone at the same time, write news and watch TV series. However, such multitasking can be a big problem, because they are not able to focus on a specific thing. Moreover, it is noted that generation $\mathrm{Z}$ was brought up without stress, and its representatives are very humble and extremely demanding, which can be a particularly difficult challenge for many employers. Not all employers are able to deal with such unruly employees. (Kostyńska, 2019).

Researchers point out that the $\mathrm{Z}$ generation as young e-consumers have several characteristics (Badzińska, 2010; Gracz, Ostrowska, 2014):

- are demanding, but open to novelties and trends,

- create and criticise new needs, attitudes and behaviours,

- are interested in innovative products and services,

- stress their differences and individuality, depart from accepted standards and stereotypes,

- their attitude towards advertising and marketing communication of companies is becoming more critical and their purchase criteria are becoming more and more rational.

To sum up, nowadays we are dealing with several generations of people active in many spheres, whose attitudes, values and types of behaviour differ quite clearly. It is worth looking at these differences in order to understand better the preferences and expectations of young people - currently students who today form the academic community of 
Polish universities. For universities, they constitute a challenge not only concerning the choice of means of communication, adjustment of forms and organisation of education, but - in the light of the described features - redefining the approach of lecturers to students, redefining the role of students in the process of education and gaining experience during several years of studies.

\section{Relations, experience and value in marketing - concept review}

In the light of contemporary research, it becomes necessary to apply new approaches to marketing in organizations, including educational institutions, such as: relationship marketing, experience marketing and value marketing. Relationship marketing focuses on building, maintaining and developing relations with various groups of university stakeholders, including, of course, students. On the other hand, experience marketing does not refer to the value of functional products and services, but - in contrast to traditional marketing - the value of contact, experience sensory, affective, cognitive, behavioral and relational nature. In practice, this means that consumer experiences appear as a result of contact, experience or participation in situations that trigger sensual, emotional and intellectual stimulation (Dziewanowska, Kacprzak, 2013). The main research currents associated with value in marketing include: creating and delivering value for the client (Doligalski, 2013), customer value management (Kumar, 2010) and customer perception of value (Gronroos, 2007).

In the 21st century, scientific papers appeared, the authors of which noticed a new role of clients as value creators and a source of innovation. In the research on co-creation of value, the valued researchers Prahalad and Ramaswama (2004) point to the evolution and transformation of customers from "passive customers" to "active players". More importantly, the new logic of value creation is to embed it in personalized experiences. A special place in this new trend of research is occupied by the marketing concept of service logic by S.L. Vargo and R.F. 
Lusch (Service Dominant Logic). The core of this concept is the idea of co-creation, which is opposite to Goods Dominant Logic. According to these authors, the value of all products for the customer (material goods and services) is created during their consumption, and the offers of producers are only value propositions (Vargo and Lusch, 2004). Service logic is also characterized by: orientation on intangible resources (operatant), not physical (operant), including in particular the appreciation of knowledge and skills, as well as striving for symmetry of information in contacts with customers and interactive dialogue with the customer and putting long-term relationships with customers above ad hoc transactions (Vargo, Lusch, 2004). The quoted concept "echoed widely in the marketing environment" and after many years was recognized and developed (Edvardsson et al., 2011; Vargo and Lusch ed., 2019).

The new marketing concepts highlighted here lead to a redefinition of the role of students in their contacts with the university, especially from the perspective of their belonging to the new $\mathrm{Y}$ and $\mathrm{Z}$ generations. In the next article we will point out the different ways of perceiving the role of students in higher education and their importance for the co-creation of values in the educational process. In the final part, we will present the segmentation of Polish students taking into account their involvement in education and their willingness to participate in a special transformation during their studies. An important aspect of the analysis will be the assessment of the possibility of using the concept of value co -creation in educational services at a higher level.

\section{The role of the student in university education - the aspect of involvement}

In research on the role of students at university, we find a description of so-called metaphors that reflect different ways of creating mental images of reality that shape students' behaviour and perception of things. Among the many metaphors found in literature, we will point to five that can be considered inspiring from the point of view of the 
discussion on co-creation of values at the university. Here are the characteristics of the selected metaphors:

1. Student as a customer of a university - a popular metaphor directly referring to traditional marketing applied to social and public institutions. In the light of this approach, students are treated as the main clients (actors) in the educational process. In practice, this means a strong orientation towards the customer - student, which provokes considerable discussions in the academic community, among others, because of the progressive codification of education at the higher level and the advantage of obtaining a diploma of graduation over gaining knowledge. Such an approach lowers the level of motivation and commitment of the studentclient and does not take into account the active role of the student.

2. Student as a product of the university - another metaphor based on the belief that "at the end of the education process we receive graduates of appropriate quality, adjusted to the needs of the labour market and social life. In practice, the university creates appropriate study programmes, takes care of the high quality of education, but also limits the student's activity.

3. Student as a professional client of the university - according to this metaphor, education is treated as a professional service based on the distinguishing knowledge and competences of the supplier. What is important, here are the relations between the parties, which should be based on trust, respect and durability. It requires active participation, involvement of the student in the education process, achievement of the set goals.

4. The student as an aspirant - this metaphor refers directly to the experience marketing, which distinguishes between buyers of experience (guests) and buyers of transformation - aspirants aspiring to a specific goal. In this approach we are dealing with an ambitious, responsible and committed student, interested in the desired transformation during university education.

5. Student as co-producer/creator - in the light of this metaphor, the student plays an active role in the education process, using available resources, directly engaging in his or her own education, showing motivation to learn. Co-production is possible here thanks to the 
clarity of the roles assigned to students, their willingness and motivation to work and their skills. Specific environmental conditions must also be met, in particular an effective management process at the university that is readily understandable to both students and lecturers, who have special roles to play in the education and socialisation of students. The research thread devoted to the relations and interactions between students and lecturers should be considered the most important for the value co-creation in the process of higher education. (Dziewanowska, 2018, p.145-158).

To sum up, an effective process of co-creating values in a university requires appropriate preparation on the part of the participants (actors) of the educational process. In particular, it concerns having an adequate level of knowledge, skills and involvement of all its participants. The student plays a double role in this process, firstly, he or she becomes a consumer of higher education services and secondly, he or she can be a co-creator of values in the whole educational process. The next point of the article is devoted to this issue.

\section{Research on co-creation of values}

in the educational process - university student perspective

Recognized marketing researchers clearly emphasize in their theoretical and practical work the need to change the approach to marketing towards value co-creation through the exchange of knowledge and skills. Conceptualisation of value co-creation visible in the research conducted in the years 1994-2016 was presented in K. Dziewanowska's work and shows a multitude of possible approaches and categories to which researchers refer in their definitions. The best known theoretical model is the so-called DART model (acronym for English terms: Dialoque, Access, Risk-benefits, Transparency) by Prahalad and Ramaswama, which has been empirically verified (Prahalad, Ramaswamy, 2004).

On the basis of a detailed analysis of the so-called research models, $\mathrm{K}$. Dziewanowska proposed her own model accurately describing the multidimensionality of co-creation of values in higher education, verified 
later in empirical studies conducted at Polish universities (with the existence of certain limitations). The model consists of the following three main dimensions of value creation in higher education:

1. co-production (including: access to information, dialogue between participants, control over the course of studies),

2. experience (including: involvement, intellectual stimulation), and

3. relations (including: between students, interaction with lecturers and administration) (Dziewanowska, 2018, p. 70-72; p. 246-247)

In this section we will refer to the latest results of empirical research by other researchers, which resulted in the identification of value creation styles by students of Polish universities. This research was carried out by K. Dziewanowska and published in a book entitled "The Value Creation Styles of Polish Universities". This research was carried out by K. Dziewanowska and published in her book entitled "Co-creating values in marketing. Example of higher education". (Dziewanowska, 2018). The study covered a total of 1,027 full-time students of three public economic universities in the field of management. The unrepresentative sample of universities is an obvious limitation for the generalisation of research results for the entire student population, but the research methodology adopted by the researcher (model and its diagnostic variables) and the research perspective (students and university lecturers) make the indicated results unique, not only onPolish but also on an international scale. The selected results of this research, quoted in this article, are certainly worth discussing in the context of generational changes at Polish universities, from the perspective of value co-creation by various participants (actors) in the educational process. Therefore, the author of the article - through the prism of the five segments of students identified in the indicated research - undertook a reflection on the significance of generational changes in the present and future didactics of universities.

Synthetic results of the research showing the student perspective are presented in the table below, which shows the importance of the dimensions of value co-creation (co-production, experience and relationships) for individual segments of students, and then relate the results to the characteristics attributed to the new generations $\mathrm{Y}$ and $\mathrm{Z}$. 
Table 2. Styles of value co-creation by Polish students - segments and their generational specificity

\begin{tabular}{c|c}
$\begin{array}{c}\text { Styles of value co-creation } \\
\text { by students }\end{array}$ & $\begin{array}{c}\text { Generational specificity } \\
\text { of student segments }\end{array}$
\end{tabular}

\section{Maximalists}

- They give the highest marks to all the dimensions of value co-creation,

- They highly evaluate the relations with lecturers and administration, the usefulness of knowledge and the conditions of studying,

- They declare their loyalty to the university,

- Relatively low level of involvement in additional activities (science clubs, workshops)
- The most numerous segment (34\% of respondents), They mostly study at the first years of their studies, (Generations $\mathbf{Y}$ and $\mathbf{Z}$ ),

- Nearly half of them work full-time.

They participate most fully in the process of value co-creating at the university.

\section{Minimalists}

- The lowest rating is given to all dimensions of value co-creation,

- Quite positively disposed only to the conditions of studying,

- They have a very low opinion of relations with lecturers,

- Little involved in additional activities.
- Small segment (15\% of respondents),

- The majority of students are students of Master's studies (Generation Y), - Most of them work full-time or part-time.

Their contribution to value co-creating is very low.

\section{Formalists}

- They highly evaluate the elements of co-production of the service: dialogue, access to information, control of studies,

- They rate relations with administration as good (better than with lecturers),

- They control the course of their education,

- Moderately interested in relationships with other students,

- Low involvement in additional activities.
- Medium-sized segment (17\% of respondents)

- The largest share of first year undergraduate students (Generation Z),

- They do not take up employment (they do not combine studies with full-time work).

Their share in value co-creating can be considered moderate.

Networkingers

\footnotetext{
- They highly value the relational dimensions of co-creating value,

- It is important to have contact with other students and to exchange knowledge,

- The main value is the other students and their interactions with them,

- They do not evaluate the other aspects: educational experience, ia, dialogue and control of the educational process.
}

- Segment of average size (20\% of respondents),

- Second and third year undergraduate students

(Generations $\mathbf{Y}$ and $\mathbf{Z}$ ) ) dominate.

- Most of them work full-time or part-time,

- Contact with others is the most important aspect of studying.

Not very active in value co-creating.

\section{Intelectuals}

- They highly evaluate the dimensions of experience: involvement in education and intellectual stimulation, - Focused on studying,

- On average they evaluate the relational dimension, they are not interested in relations with other students, - They moderately control studies,

- Relatively low level of involvement in additional activities.
- Small segment (14\% of respondents),

- The dominating students are the first year of MA studies (Generation Y),

- Appreciating the intellectual effort

- They are relatively less likely to take up employment during their studies,

Moderately active in value co-creating.

Source: elaboration prepared on the basis of research by K. Dziewanowska, 2018, pages 256-272. 


\section{Conclusions of the study}

A number of synthetic conclusions can be drawn from the analyses and evaluations carried out. They refer to the attitudes and behaviours of students that we deal with in today's university, in the context of the participation of students in value co-creation in the educational process:

1. The analysed generation $\mathrm{Y}$ and the younger generation $\mathrm{Z}$ are currently the community of students of Polish universities. Specific features assigned to this generation influence attitudes towards three dimensions of co-creating values: co-production (including: access to information, dialogue, control over studies), experience (including: involvement, intellectual stimulation) and relations (including: between students and interaction with lecturers and administration).

2. There are many metaphors that reflect different ways of creating mental images of reality that shape students' behaviour and perception of the university. Among the analyzed metaphors, three can be identified, which indicate a certain level of student involvement in the educational process in the analyzed dimensions, enabling the co-creation of values in education. These metaphors include: student as a professional client of the university (appreciates relations, uses available knowledge resources), student as an aspirant (interested in acquiring knowledge and its use) and student as a coproducer/creator (uses available knowledge resources, highly motivated and engaged, values relations with other participants of the learning process).

3. Generation $\mathrm{Y}$ and $\mathrm{Z}$ students can be assigned specific styles of cocreating values in the educational process at university. The student segments that participate most fully in this process are Maximalists of the $\mathrm{Y}$ and $\mathrm{Z}$ generation. Their attitudes and behaviours are characterized by commitment to education, care for relations, loyalty to the university and effective use of available resources. Students who moderately participate in value co-creation are the segments of Formalists (generation Z, bachelor's degree studies) and Intellectuals 
(generation Y, master's degree studies). They differ in their attitude to work during their studies, their commitment to learning. The lowest share in co-creation of values is reported by Minimalists from generation $\mathrm{Z}$ and Networkingers from generation $\mathrm{Y}$ and $\mathrm{Z}$. They value relationships with other students and work during their studies.

4. The concept of Vargo and Lusch service logic of co-creation is used in higher education services. The student segments that are most involved in co-creation of higher education services, i.e. Maximalists, show typical attitudes towards this concept: they are oriented towards intangible resources (knowledge), acquire information, participate in a dialogue, value relationships, build interactions with other participants of the education process. Therefore, it can be stated that the educational offer of the university is for them a proposal of education which they actively use and thus influence the features of their own educational experience.

5. The generational changes of Polish students presented in the article refer to the results of research carried out at economic universities, to the direction of management, creating specific limitations for conclusions on the behavior of the entire student population. However, in subsequent research projects there is usually no continuity, repeatability allowing for the verification of hypotheses, adopted research methodology, verification of results. I believe that the research methodology proposed in K. Dziewanowska's (2018) publication is very valuable and universal and should encourage Polish researchers to continue research on value co-creation in education in other fields of study and profiles of universities.

6. Certainly, the continuation of scientific research on co-creating values in higher education is a fruitful and desirable direction of research in the light of the development of a marketing concept based on the idea of value co-creation. Also the developing concept of service logic of domination may be an important support for the direction of further research. It is also worth emphasising that the results of research in this area may prove to be fundamental for the practice of university operations, especially the preparation of an effective educational strategy and shaping the image of the university in the near future. 


\section{Bibliography}

1. Albrychiewicz-Słocińska A., Robak E. (2017). Pozyskiwanie pracowników z pokolenia $\mathrm{Y}$ - wybrane praktyki organizacyjne z zakresu marketingu rekrutacyjnego. Zeszyty Naukowe Politechniki Częstochowskiej. Zarzadzanie, No. 28. pp.152-153.

2. Badzińska E. (2010). Tendencje na rynku młodych konsumentów, [In:] Wyrwicka M. K. (red.), Tendencje rozwojowe Wielkopolski $w$ kontekście transformacji wiedzy $w$ sieciach gospodarczych, Poznań: Wyd. Politechniki Poznańskiej, p. 175.

3. Doligalski, T. (2013). Internet $w$ zarzadzaniu wartościa dla klienta. Warszawa: Oficyna Wydawnicza Szkoły Głównej Handlowej.

4. Dziwanowska K., Kacprzak A. (2013). Marketing doświadczeń. Geneza i rozwój. Warszawa: PWN. p. 87.

5. Dziewanowska K. (2018). Wspóttworzenie wartości w marketingu. Przyktad szkolnictwa wyższego. Warszawa: Wydawnictwo C.H. Beck. p. 145-146.

6. Edvardsson, R. N. at all, (2011). Does service dominant design result in a better service system? Journal of Service Management, 22(4).

7. Gadomska-Lila K. (2015). Pokolenie Y wyzwaniem dla zarządzania zasobami ludzkimi. Zarzadzanie Zasobami Ludzkimi, No. 1. p. 25-39.

8. Główny Urząd Statystyczny (2017). Młodzi ludzie na rynku pracy. Warszawa: Główny Urząd Statystyczny.

9. Gołąb-Andrzejak E. (2016). Konsumenci pokolenia Y — nowe wyzwanie dla komunikacji marketingowej. Handel Wewnętrzny, No. 2. p. 140-151.

10. Gracz L., Ostrowska I. (2014). Młodzi nabywcy na e-zakupach. Warszawa: Agencja wydawnicza Placet, p. 73.

11. Grönroos, Ch. (2007). In Search of New Logic for Marketing. Foundations of Contemporary Theory. London: John Wiley \& Sons, Ltd.

12. Kisiel P. (016). Milenialsi - nowy uczestnik życia społecznego?, Studia Socialia Cracoviensia, 1(14). p. 83-94.

13. Kostyńska, M. (2019). Pokolenie Z, czyli pokolenie nowoczesnych technologii i internetu. https://msp.money.pl/wiadomosci/poradniki/artykul/pokolenie-z-czyli-pokolenienowoczesnych, 81,0,2419537.html (22.08.2019).

14. Kumar V. (2010). Zarzadzanie wartościa klienta. Warszawa: PWN.

15. Nielsen Company (2014). Millennials - breaking the myths, http://www.nielsen.com/us/en/insights/reports/2014/millennials-breaking-the-myths.html, (22.08.2019).

16. Prahalad, C. K., Ramaswamy, V. (2004). The future of competition: Creating unique value with customers. Boston: MA Harvard.

17. Rusak P. (2014). X, Y, Z pokoleniowa bitwa biurowa. Rynek Pracy. Przewodnik Pracodawcy, No. 1. p. 11-12.

18. Tapscott D. (2010). Cyfrowa dorostość. Jak pokolenie sieci zmienia nasz świat. Warszawa: WAiP, p. 53-59.

19. Van den Bergh J., Behrer M. (2012a). Jak kreować marki, które pokocha pokolenie Y?. Warszawa: Edgard, seria Samo Sedno. p. 23.

20. Van den Bergh J., Behrer M. (2012b). Jak kreować marki, które pokocha pokolenie Y?. Warszawa: Edgard, seria Samo Sedno. p. 139-141. 
21. Vargo, S. L., Lusch, R. F. (2004). Evolving to a New Dominant Logic for marketing. Journal of Marketing, 68(1).

22. Vargo, S. L., Lusch R. F. ed. (2019). The SAGE Handbook of Service - Dominat Logic. London: Sage Publications Ltd., p. 3-21.

23. Viacom International Media Networks. (2017). The Next Normal: An Unprecedented Look At Millennials. https:/www.mediabuzz.com.sg/research-oct-13/the-next-normal-an-unprecedented-look-at-millennials-worldwide. (22.08.2019).

Mirosława Pluta-Olearnik - Professor of the Wroclaw University of Economics, in Department of Marketing. Professor of economics, academic teacher, service management and marketing specialist, research team leader. Cooperates with national and foreign publishing houses (scientific board member, reviewer, editor). For many years she has been specialized in the issues of marketing and development of different service sectors. She is the author of many scientific publications, including such books as "Services Marketing"; "Banking Services Marketing"; "The Development of Educational Services in the Higher Educational Organizations; "The enterprising university and its relations"; Marketing of service enterprises in the internationalization process" and many scientific articles. An active participant as an author of papers or moderator of discussions at many scientific conferences in the economics, management, marketing fields. 